\title{
U.S. Cross-Border Derivatives Data: A User's Guide
}

\author{
Stephanie E. Curcuru, of the Board's Division of \\ International Finance, prepared this article. Jonas J. \\ Robison provided research assistance.
}

The global derivatives market has grown rapidly in the past decade. By one measure of market size-the notional value, which is used to determine the payments made on a derivatives contract - the derivatives market expanded from $\$ 87$ trillion in June 1998 to $\$ 454$ trillion in June 2006 (figure 1). ${ }^{1}$ Measured by the price at which a derivatives contract can be purchased in a current transaction, or the market value, the derivatives market grew from $\$ 3$ trillion in June 1998 to $\$ 10$ trillion as of June 2006.

Available data suggest that cross-border derivatives deals-in which a resident of one country enters into a contract with a resident of another countrymake up a substantial share of derivatives transactions. ${ }^{2}$ Recognizing this fact, the International Monetary Fund (IMF) has recommended that its member countries include cross-border derivatives in their reports on external-sector finances. ${ }^{3}$ Many countries with financial services firms active in the derivatives market have included derivatives in these reports since the mid-1990s. The United States, however, has to date published very little information on cross-

1. The notional value of a derivative is specified in the contract and serves as one basis for computing the payments made on the contract. For example, for a contract known as a foreign exchange forward, in which two parties agree to exchange an amount of currency at a future date, the notional value is the amount of currency to be exchanged.

2. For example, data for the United Kingdom indicate that crossborder derivatives with a positive market value to the domestic counterparty totaled $\$ 1.8$ trillion in that country at the end of 2005 . Refer to Office of National Statistics (2006), United Kingdom Balance of Payments: The Pink Book 2006 (New York: Palgrave Macmillan). Data for other countries are available in the Balance of Payments Statistics Yearbook, published annually by the International Monetary Fund.

3. In 1993 the IMF recommended including derivatives as a line item under the reporting category of "portfolio investment"; in 1998 it further recommended that member countries report such data as a separate reporting category_- "financial derivatives." Refer to International Monetary Fund (1993), IMF Balance of Payments Manual, 5th ed. (Washington: IMF); and International Monetary Fund (1998), "Financial Derivatives," paper prepared for the Eleventh Meeting of the IMF Committee on Balance of Payments Statistics, held at the International Monetary Fund, Washington, Oct. 21-23, www.imf.org/ external/bopage/agenda.htm.
1. Gross market value and notional value of global derivatives outstanding, 1998-2006

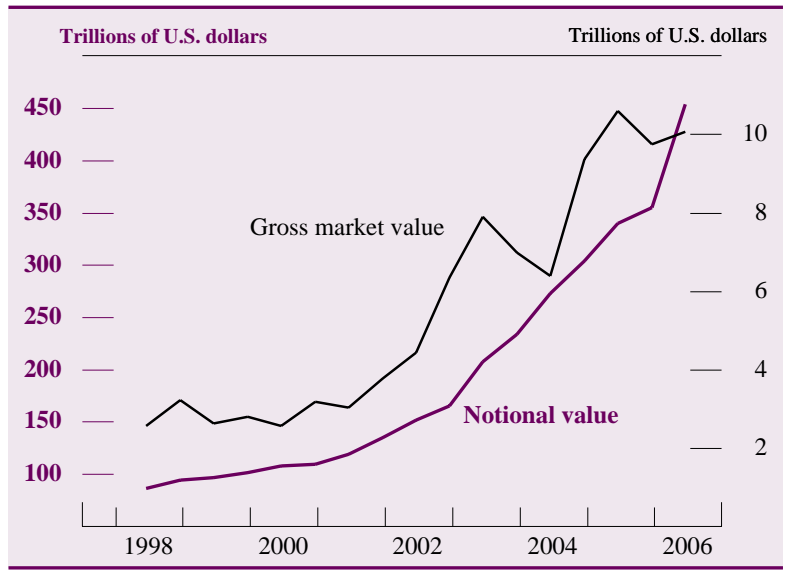

Note: The data are semiannual and extend through June 2006. Gross market value is the sum of the total gross positive market value of contracts with all counterparties and the absolute value of the total gross negative market value of contracts with nonreporting counterparties. The term gross indicates that for multiple contracts with the same counterparty, contracts with positive market values and contracts with negative market values are no netted. For an explanation of notional value, refer to text note 1 . To adjust for double counting, the notional values of contracts with reporting counterparties are divided by 2 .

SourcE: Bank for International Settlements.

border derivatives because of the limited availability of data. ${ }^{4}$ As a result, U.S. reports on cross-border financial flows and holdings currently exclude the bulk of transactions and positions in cross-border derivatives.

To address these gaps in data and reporting, the U.S. Department of the Treasury, the Federal Reserve Bank of New York, and the Federal Reserve Board began collecting data on U.S. cross-border transactions and positions in derivatives in March 2005. They collect the data through the Treasury International Capital (TIC) reporting system, which for many years has collected similar data for securities such as stocks and bonds. ${ }^{5}$ Because existing TIC

4. Some cross-border transactions in exchange-traded futures are included in the quarterly U.S. balance of payments data, table 8a, line B18 ("Commercial liabilities; Advance receipts and other liabilities"), available at www.bea.gov/international.

5. The TIC reporting system collects information on cross-border transactions in, and holdings of, portfolio securities and on other claims and liabilities, including deposits. Reports are filed by banks 
reporting forms were ill equipped to capture crossborder derivatives transactions and positions, the Treasury developed a new form specifically for this purpose-TIC form D.

This article introduces the new data collected by form $\mathrm{D}$ and provides helpful information for data users. The article begins with a discussion of the relevance of derivatives to the U.S. external-sector reports published by the U.S. Department of Commerce, Bureau of Economic Analysis. To date, derivatives have been largely excluded from these reports. The article explains in detail the effects of the exclusion on two such reports- the U.S. balance of payments and the U.S. international investment position. In particular, it shows how the omission of derivatives from reports on cross-border flows and holdings can lead to mistaken inferences about what is driving changes in the international investment position of the United States. The implications of the analysis extend beyond the omission of derivatives. The effect of any other systematic omission of data on the external-sector reports may be similar.

The article then summarizes the information collected by form D and shows how the data will improve external-sector reporting. It also presents the 2006 data and discusses their relation to the derivatives data reported by other countries. The article concludes with a discussion of the use of the data to estimate risk exposures. Because the terminology associated with derivatives can be somewhat daunting, detailed definitions are provided in the boxes accompanying the main text.

\section{DERIVATIVES AND THE U.S. EXTERNAL- SECTOR REPORTS}

The purpose of TIC form D is to collect the information needed for the inclusion of cross-border derivatives transactions and holdings in U.S. external-sector reports. This section examines the effect of the inclusion of derivatives data in external-sector reports through examples of accounting entries in two such reports. The examples illustrate the current and future treatment of derivatives transactions in the U.S. balance of payments as well as the current and future treatment of derivatives holdings in the U.S. international investment position.

\section{Types of Derivatives}

A derivative is a financial contract whose value is derived from something else (such as the value of a

and bank holding companies; securities brokers, dealers, and custodians; and nonfinancial companies with sizable commercial or financial claims and liabilities vis-à-vis foreign residents. stock or bond), referred to as the "underlying." Anything that can be measured can serve as the underlying to a derivative. The underlying can be the price of a stock, the yield on a bond, a credit rating, the value of an index, or even something more exotic, like the average temperature in a region over a given period.

Common types of derivatives include options, forwards, futures, and swaps. In an options contract, the buyer pays an up-front premium for the right, but not the obligation, to purchase or sell a specified quantity of the underlying at a specified price on (or, in some contracts, until) the expiration date. The two parties to a forward or futures contract agree to exchange assets or their cash equivalent at, or until, a future date. The two parties to a swap agree to exchange assets or their cash equivalent periodically until a future date (for more information, refer to box "Overview of Derivatives").

\section{The U.S. Balance of Payments}

A country's balance of payments (BOP) is the record of the economic transactions between its residents and those of the rest of the world in a given period. The Bureau of Economic Analysis (BEA) publishes the U.S. BOP quarterly in three sections: the current account, the capital account, and the financial account. ${ }^{6}$ The current account records transactions in goods and services, income, and unilateral transfers between residents of the United States and nonresidents. Items recorded in the capital account include nonproduced assets and other capital transfers, such as debt forgiveness and transfers of goods and financial assets by foreign residents as they enter or leave the United States. Transactions in the current and capital accounts give rise to financial flows, which are recorded, in turn, in the financial account. The financial account also records cross-border transactions arising from trade in financial instruments such as stocks and bonds, including transactions associated with the purchase or sale of the securities and those associated with payment for them.

Transactions in the BOP accounts are recorded as credit or debit entries (refer to box "Accounting in the U.S. Balance of Payments"). Credit entries are given a positive sign, and debit entries a negative sign. Transactions that generate a receipt of funds into the United States, such as an export, the sale of a security to a foreign resident, the withdrawal of U.S. deposits from a foreign bank, and the deposit of funds

6. Before 1999, the BOP had only two sections-the current account and the capital account. The capital account included items that now appear in the financial account. 


\section{Overview of Derivatives}

A derivatives contract can take many forms, but each form has one thing in common-the value of the contract is derived from something else, such as the value of a stock or bond; that "something else" is referred to as the underlying. As noted in the main text, anything that can be measured can serve as the underlying to a derivative. The following discussion covers several common types of derivatives, their associated cash flows, and their uses. Most other types of derivatives are variants of those discussed here.

\section{Forward Contract}

A forward contract is an agreement to purchase or sell a specified quantity of an underlying asset or its cash equivalent at a stated price on the given maturity date of the contract. Forwards trade in the over-the-counter (OTC) market, in which contract terms are negotiated between each pair of counterparties. Forwards typically have a zero initial cost to the contracting parties-that is, the counterparties set the delivery price so that each is willing to enter into the contract without an initial payment. The only payment is on the maturity date, when the counterparties will either exchange the assets specified in the contract or their cash equivalent. ${ }^{1}$

Forwards can be used to lock in, or "hedge," future expenses. They provide protection against future adverse movements in the value of the underlying asset, but they do so at the expense of losing future gains from favorable movements. For example, consider a firm that imports products into the United States. If the value of the U.S. dollar falls relative to the foreign currency, the dollar cost of the imported products will rise. To limit potential losses from exchange rate moves, the firm can enter into a foreign exchange forward contract to exchange a specified quantity of U.S. dollars for a specified quantity of the foreign currency at a future date, thereby locking in the exchange rate.

\section{Swap Contract}

A swap contract is basically a series of forwards, all with the same delivery price and quantity. As with individual forwards, swaps trade in the OTC market, and many are zero cost. Interest rate swaps are commonly used to change the flows of claims or liabilities from fixed to floating, or vice versa. For example, if a firm desires a loan with a fixed interest rate but can obtain a more favorable loan with a floating rate, the firm may choose the floating-rate loan and then enter into an offsetting swap agreement in which it pays a fixed rate and receives a floating rate. Because a swap is equivalent to a series of forwards, the counterparties will exchange assets or their cash equivalents periodically over the life of the contract.

1. Generally, forward contracts are not sold before maturity. Instead, one or both parties to the contract will enter into an offsetting contract with a third party.

\section{Futures Contract}

A futures contract is similar to a forward contract, but it trades on an organized exchange with standardized contract terms, including maturity date and quantity. Futures are subject to daily settlement to limit credit exposure. Each day, the current value of the contract, the "variation margin," is added to or subtracted from the owner's account, thereby returning the value of the contract to zero. Traders are required to maintain enough funds on deposit in a margin account to cover potential losses.

As with forwards and swaps, futures are also typically zero cost. ${ }^{2}$ However, because of daily settlement, many cash flows occur between the purchase date and the sale or maturity date. Futures can be used for the same hedging purposes as forwards.

\section{Option Contract}

The owner of an option has the right, but not the obligation, to purchase (call option) or sell (put option) a fixed quantity of the underlying asset at a predetermined price, the strike price, on a predetermined date, the exercise date. Unlike forwards, swaps, and futures, which are typically zero cost, options can have a sizable initial cost, or premium. To the option purchaser, the option premium represents the maximum potential loss, whereas for forwards, swaps, and futures, the loss potential of both counterparties is unlimited. A call (or put) option has value if the possibility remains that the price of the underlying will be above (or below) the strike price on the exercise date. An option is "in the money" if the current price of the underlying is above (call option) or below (put option) the strike price. Options trade in the OTC market, with customized contract terms between the two parties; and on exchanges, with standard contract terms, such as set dates, strikes, and notional amounts.

For calls and puts, one of three scenarios is possible before or on the expiration date. If the option is sold, the sale proceeds are transferred to the owner. If the option is in the money on the expiration date, funds are transferred to the owner, and the amount transferred corresponds to the difference between the strike price and the price of the underlying, multiplied by the quantity of the underlying specified in the contract. ${ }^{3}$ If the option expires worthless, no funds are transferred.

Options can be used for the same hedging purposes as other derivatives. For example, a firm seeking protection against adverse exchange rate movements can enter into an option contract to exchange a quantity of currency or its cash equivalent at a future date if the exchange rate moves beyond the strike price.

2. For exchange-traded derivatives, an initial margin deposit is required before the start of trading. Unless it is in the form of securities, the deposit is recorded as a banking transaction, not a derivatives transaction. When securities are used as margin deposits, no banking or other category of transaction is recorded.

3. This example assumes that the option contract specifies cash settlement as opposed to physical settlement. If the option underlying is an equity or commodity, physical settlement will involve actual physical delivery of the underlying, whereas cash settlement will involve an exchange of cash equal to the intrinsic value of the option. 


\section{Accounting in the U.S. Balance of Payments}

Transactions in the U.S. balance of payments (BOP) are recorded on the basis of the double-entry system of accounting. ${ }^{1}$ In this system all transactions are classified as debits or credits. For every debit entry there must be a corresponding credit entry; hence the term double entry. Corporations use this accounting method in preparing their financial statements. In corporate financial statements, receipts and expenses, as well as assets and liabilities, are shown as positive numbers, and balances are derived through subtraction. For example, expenses are deducted from receipts to derive net income, and liabilities are deducted from assets to derive net worth. In the BOP the convention is somewhat different. Transactions that generate credit entries in an accounting sense (increases in liabilities or decreases in assets, or increases in revenues or decreases in expenses) are shown with a positive sign in the balance of payments, and transactions that generate debit entries (decreases in liabilities or increases in assets, or decreases in revenues or increases in expenses) are shown with a negative sign; the positive and negative entries are added to derive BOP balances, such as the balance in the current account, the capital account, or the financial account.

A single international transaction will frequently involve four parties - a purchaser, a seller, and their respective banks - and each party that is a U.S. resident will contribute one or more entries to the BOP, possibly in more than one accounting period. For example, when a U.S. resident purchases a bond from a foreign resident, U.S. holdings of foreign securities will rise (a debit entry in the BOP) and liabilities to foreign residents will also rise in recognition of the new obligation to pay for the bond (a credit entry). When the U.S. investor pays for the bond in the subsequent accounting period, its own

1. Additional information is in Bureau of Economic Analysis (1990), The Balance of Payments of the United States: Concepts, Data Sources, and Estimating Procedure (Washington: BEA, May), www.bea.gov/scb/ pdf/internat/bpa/meth/bopmp.pdf. liabilities to foreign residents will fall to zero (a debit entry) and its bank's liabilities to foreign residents will increase (a credit entry). The means by which U.S. bank liabilities increase may not be obvious. The increase occurs because the U.S. investor could extinguish its liability by issuing a check against its account at a U.S. bank, which the foreign investor would deposit at its local bank abroad. That bank would, in turn, present the check to the U.S. investor's U.S. bank for settlement. Thus, the series of transactions ultimately results in an increase in foreign bank claims on U.S. banks and an increase in U.S. holdings of foreign securities.

The BOP uses a similar accounting treatment for imports or exports of goods and services. When a business purchases goods from a foreign resident, U.S. imports will rise (a debit entry in the BOP), and liabilities to foreign residents will also rise because of the new obligation to pay for the imported goods (a credit entry). When the U.S. importer pays for those goods, its own liabilities to foreign residents fall to zero (a debit entry), and its bank's liabilities to foreign residents increase (a credit entry).

A transaction may be recorded in one or more BOP accounts depending on the type of transaction. Some transactions, such as the purchase of a foreign bond, result in only financial account entries, whereas others, such as the importation of goods, result in entries in more than one set of accounts (in the example of goods purchased from a foreign resident, both the current account and the financial account recorded entries). Nonetheless, transactions summed across all BOP accounts should equal zero because, in principle, each transaction should have a corresponding positive or negative entry. Incomplete or erroneous information affects the "statistical discrepancy" in the BOP. The statistical discrepancy is derived by summing all recorded BOP transactions and reversing the sign of the total; it reflects the (net) value of all BOP entries during a given period that were not fully or correctly captured in the accounts. in a U.S. bank by a foreign resident, are each recorded with a credit (positive) entry. They have offsetting debit (negative) entries to reflect transactions that generate payments of funds to foreign residents. For example, an import, the purchase of a security from a foreign resident, the deposit of new or additional U.S. funds in a foreign bank, and the withdrawal of a foreigner's deposit from a U.S. bank are each recorded with a debit (negative) entry. Because of this accounting convention, the international transactions accounts should always have a zero balance, as every positive entry in the BOP should have a corresponding negative entry.

For most current account transactions, the offsetting entry is in the financial account. For example, a U.S. firm's purchase of steel from a foreigner gener- ates a debit (negative) entry in the current account for the imported steel. The associated payment is recorded as an offsetting positive entry in the financial account and can take any of several forms, including decreased U.S. deposits in a foreign bank or increased foreign deposits in a U.S. bank.

\section{Accounting for Financial Instruments Other Than Derivatives}

Many transactions do not involve a current account payment or receipt but instead are recorded entirely in the financial account. For example, for transactions that involve the purchase or sale of financial instruments such as stocks or bonds, both the change in financial instrument holdings and the offsetting in- 
1. Example of entries in the financial account of the U.S. balance of payments: Purchase by a foreign resident of a U.S. stock from a U.S. resident, and subsequent sale of the stock

U.S. dollars

\begin{tabular}{|c|c|c|}
\hline \multirow{2}{*}{ Foreign-owned assets in the United States } & \multicolumn{2}{|c|}{ Financial flow } \\
\hline & Year 1 & Year 2 \\
\hline U.S. securities other than U.S. Treasury securities & 100 & -50 \\
\hline $\begin{array}{l}\text { U.S. liabilities reported by U.S. banks, } \\
\text { not included elsewhere }\end{array}$ & -100 & 50 \\
\hline Statistical discrepancy & 0 & 0 \\
\hline
\end{tabular}

NoTE: Here and in subsequent tables, refer to text for details; a positive value indicates a net financial inflow to the United States, and a negative value indicates a net financial outflow from the United States.

crease or decrease in deposits are reported in the financial account. For most financial account transactions, the relevant information is collected through the TIC system. ${ }^{7}$

By way of illustration, suppose that in year $1 \mathrm{a}$ foreign resident purchases $\$ 100$ of U.S. stock through a U.S. broker using funds that had been on deposit at a U.S. bank (table 1). The U.S. financial services firms that facilitate this cross-border transaction are responsible for reporting it on the TIC forms. The U.S. broker in the example is responsible for reporting the stock purchase in its monthly report of TIC securities transactions. The U.S. bank records the foreigner's deposit balance at the end of each month on the TIC banking report; the decline in deposits is inferred from changes in these month-end balances.

In the example, the values reported through the TIC system generate two financial account entries. The account for U.S. securities held by foreigners ("U.S. securities other than U.S. Treasury securities") increases by $\$ 100$, which is the purchase price of the stock, shown as a positive amount, or credit. The account of U.S. banking liabilities to foreigners ("U.S. liabilities reported by U.S. banks, not included elsewhere") decreases by the $\$ 100$ used to purchase the stock, shown as a negative amount, or debit.

Continuing with the example, also suppose that the value of the stock falls to $\$ 50$ and that in the second year the foreign resident sells the $\$ 50$ worth of stock. After the sale, the cash proceeds are transferred to the U.S. bank account of the foreign resident, and so the banking deposit balance of the foreign resident increases by an amount equal to the proceeds from the sale of the stock and will be captured on the monthly

7. Exceptions are direct investment, currency shipments, and some U.S. government transactions, all of which are collected through other means. The TIC data include commissions paid to intermediaries, which are recorded in the current account, not the financial account. The BEA adjusts the TIC data by subtracting estimated brokerage commissions to determine financial account transactions.
TIC banking reports. As with the stock purchase, the stock sale will be included in the reports of TIC securities transactions. Accordingly, two financial account entries arise from values reported through the TIC system: a decrease (debit) of $\$ 50$ in U.S. securities held by foreigners and an increase (credit) of the same amount in U.S. banking liabilities to foreigners. No entry in the financial account records the change in the stock value. ${ }^{8}$

The final line in the BOP is a reconciliation line labeled "statistical discrepancy." Because the BOP is based on the double-entry accounting system, the sum of all current account, capital account, and financial account transactions should equal zero. Any remaining balance due to errors or omissions in the recorded international transactions is reported as a statistical discrepancy. In the example of the stock purchase and sale, each transaction has an exactly offsetting transaction within the financial account, the sum of all transactions recorded in each year is zero, and therefore no statistical discrepancy arises in either year.

The current presentation of the U.S. financial account includes direct investment, securities (stocks and bonds), currency, and loans and deposits (banking and brokerage). Transactions in all these instruments are recorded in the financial account as described in the example, but transactions in derivatives contracts are recorded on only a limited basis.

\section{Accounting for Derivatives}

As with transactions involving stocks or bonds, transactions involving derivatives are recorded in the financial account as increases or decreases in U.S. banking claims on, or liabilities to, foreigners. However, to date, no corresponding entry in the financial account reflects the change in the quantity of U.S. derivatives claims on, or liabilities to, foreigners. Thus, the international transactions accounts shown in the BOP capture only one side of most derivatives transactions. ${ }^{9}$

The effect of the incomplete accounting for derivatives transactions in the BOP can be seen in the following example. Suppose that instead of purchasing a U.S. stock from a U.S. broker, as in the earlier example, a foreign resident purchases a derivative (such as an option) for $\$ 100$ from a U.S. resident with funds on deposit in a U.S. bank (table 2). The change in the foreigner's deposit balance, reported by the U.S. bank at the end of each month on its TIC

8. Valuation changes are included in the U.S. international investment position, discussed later in the article.

9. The BEA plans to include derivatives in the U.S. BOP starting in June 2007. 
2. Example of entries in the financial account of the U.S. balance of payments: Purchase by a foreign resident of a derivative from a U.S. resident, and subsequent sale of the derivative

U.S. dollars

\begin{tabular}{c|cc}
\hline \multirow{2}{*}{ Foreign-owned assets in the United States } & \multicolumn{2}{|c}{ Financial flow } \\
\cline { 2 - 3 } & Year 1 & Year 2 \\
\hline $\begin{array}{r}\text { U.S. financial derivatives liabilities }{ }^{1} \ldots \ldots \ldots \ldots \ldots \ldots \ldots \\
\text { U.S. liabilities reported by U.S. banks, }\end{array}$ n.a. & n.a. \\
not included elsewhere $\ldots \ldots \ldots \ldots \ldots \ldots \ldots \ldots \ldots$ & -100 & 50 \\
Statistical discrepancy $\ldots \ldots \ldots \ldots \ldots \ldots \ldots \ldots \ldots \ldots$ & 100 & -50 \\
\hline
\end{tabular}

1. Transactions in derivatives liabilities are shown for illustrative purposes only. As discussed later in the article, derivatives transactions are collected on a net basis and will appear on that basis in the BEA's presentations of the U.S. balance of payments and the U.S. international investment position. n.a. Not available.

banking report, reflects the banking transaction associated with the purchase of the derivative (in addition to banking activity arising from other transactions). The deposit balance is reported to the compilers of the financial account, and so a decrease (debit) in U.S. banking liabilities to foreigners equal to the purchase price of the derivative, or $\$ 100$, is recorded in that account.

However, in the absence of TIC form D, the U.S. resident has no way of reporting a purchase or sale of a derivative, as this type of transaction is recorded on no other TIC report. As a result, the compilers of the financial account have no way of knowing that the banking transaction was for the purchase of a derivative, and thus no entry in the financial account reflects the increase in derivatives liabilities to foreigners. The failure to record a credit entry for the changes in derivatives liabilities creates an imbalance in the international transactions accounts, which results in a statistical discrepancy of $\$ 100$, the purchase price of the derivative. ${ }^{10}$

Also suppose that during year 1 the value of the derivative falls to $\$ 50$ and that in year 2 the foreign resident sells the derivative. After the sale the $\$ 50$ proceeds are transferred to the U.S. bank account of the foreign resident. Because banking deposits are reported on the TIC banking reports, an increase in U.S. banking liabilities of $\$ 50$ is recorded in the financial account when the derivative is sold. However, nothing in the financial account reflects the decrease in derivatives liabilities to foreigners, and so a statistical discrepancy of negative $\$ 50$, equal to the proceeds from the sale of the derivative, results in year 2. This example illustrates how the current BOP

10. The statistical discrepancy is found by summing all recorded transactions and reversing the sign of the total. In this example, the only recorded transaction is negative $\$ 100$, and so the statistical discrepancy is positive $\$ 100$. reporting system, in which data on cross-border derivatives transactions are incompletely recorded, gives rise to a statistical discrepancy in the BOP accounts.

\section{The U.S. International Investment Position}

Like the BOP, the U.S. international investment position (IIP) currently includes only a limited amount of derivatives claims and liabilities. The IIP reports the value of U.S.-owned assets abroad and that of foreignowned assets in the United States. In other words, it reports the current value of the assets accumulated through the transactions recorded in the financial account of the BOP. In the IIP, the BEA decomposes each outstanding position at the end of each calendar year into three parts: the position at the end of the previous year, net transactions recorded in the BOP during the current calendar year, and valuation adjustments attributable to changes in exchange rates, prices, and other factors, such as the inclusion of data from new reporters.

Accounting for Financial Instruments Other Than Derivatives

The categories in the IIP are similar to those in the financial account of the BOP, and the transactions reported in the IIP come directly from the BOP. As previously mentioned, U.S. banking deposit claims on, and liabilities to, foreigners are collected on the monthly TIC banking reports; these data are used in the IIP. For the U.S. stock and bond holdings of foreign residents and the foreign stock and bond holdings of U.S. residents, the custodial firms holding the securities report them on periodic TIC surveys of claims and liabilities, and the BEA uses the holdings information to construct the IIP.

The presentation of holdings on the IIP can be illustrated with a variation on the previous example of the purchase and eventual sale of U.S. stock by a foreign resident. Besides the details already mentioned, we suppose that the foreign resident has \$200 on deposit at a U.S. bank at the end of year 0 and that the deposit balance is reported as the year-end position on the IIP for that year (table 3). Using the BOP transactions data from the earlier example, the IIP for year 1 reports an increase in U.S. securities held by foreigners and a decrease in U.S. banking liabilities to foreigners, both of which correspond to the purchase price of the stock $(\$ 100)$. As before, we suppose that the value of the stock decreases by $\$ 50$ between the purchase date and the end of year 1 . The year-end market value of the stock, as reported on the TIC 
3. Example of entries in the U.S. international investment position: Purchase by a foreign resident of a U.S. stock from a U.S. resident, and subsequent sale of the stock

U.S. dollars

\begin{tabular}{|c|c|c|c|c|c|c|c|}
\hline \multirow[b]{2}{*}{ Foreign-owned assets in the United States } & \multirow{2}{*}{$\begin{array}{c}\text { Year } 0 \\
\begin{array}{l}\text { Ending } \\
\text { balance }\end{array}\end{array}$} & \multicolumn{3}{|c|}{ Year 1} & \multicolumn{3}{|c|}{ Year 2} \\
\hline & & $\begin{array}{l}\text { Transaction } \\
\text { recorded in } \\
\text { BOP }\end{array}$ & $\begin{array}{c}\text { Valuation } \\
\text { adjustment }\end{array}$ & $\begin{array}{l}\text { Ending } \\
\text { balance }\end{array}$ & $\begin{array}{l}\text { Transaction } \\
\text { recorded in } \\
\text { BOP }\end{array}$ & $\begin{array}{l}\text { Valuation } \\
\text { adjustment }\end{array}$ & $\begin{array}{l}\text { Ending } \\
\text { balance }\end{array}$ \\
\hline \multirow{2}{*}{$\begin{array}{l}\text { U.S. securities other than U.S. Treasury securities } \\
\text { U.S. liabilities reported by U.S. banks, } \\
\text { not included elsewhere ........................ }\end{array}$} & 0 & 100 & -50 & 50 & -50 & 0 & 0 \\
\hline & 200 & -100 & 0 & 100 & 50 & 0 & 150 \\
\hline Total & 200 & 0 & -50 & 150 & 0 & 0 & 150 \\
\hline
\end{tabular}

BOP U.S. balance of payments.

holdings survey, is recorded in the IIP as the ending balance for year $1(\$ 50)$. The IIP reports this $\$ 50$ decline in value as a valuation adjustment due to price changes. For year 1, the value of the total position decreases by the amount of the valuation adjustment, to $\$ 150$. If the stock is sold before the end of year 2 and there are no further price changes, the total value of the position is unchanged. At the end of year 2, no stock claims by foreigners remain-only a banking deposit balance.

The IIP captures only the banking deposit transactions and positions associated with purchases and sales of cross-border derivatives. Just as cross-border derivatives transactions go largely unrecorded in the BOP, so cross-border derivatives positions are also mostly missing from the IIP.

\section{Accounting for Derivatives}

The current treatment of derivatives in the BEA's presentation of the IIP is illustrated by the next example, in which a foreign resident purchases a derivative instead of a stock from a U.S. resident (table 4). A recorded transaction will reflect the decrease in U.S. bank liabilities to foreigners corresponding to the purchase price of the derivative, and the remaining balance of $\$ 100$ in U.S. bank liabilities to foreigners will be correctly reported at the end of year 1. As in the BOP, no transaction corresponding to the purchase of the derivative will be reported. Although the value of the derivative decreases to $\$ 50$ before the end of year 1, the IIP will not report the valuation adjustment. The total foreign liability position of $\$ 100$ at the end of year 1 will include the correct value of the banking deposits but not the value of the derivative. When the derivative is sold in year 2 , the increase in U.S. banking liabilities to foreigners equal to the total sale proceeds (\$50) will be recorded correctly, but no transaction will reflect the decreased derivatives liabilities to foreigners resulting from the sale of the derivative.

The positions at the end of years 0 and 2 on the IIP are both correct, as derivatives were held at the end of neither of those years-only at the end of year 1 . However, total transactions and total valuation adjustments over the two-year period are both incorrect. The IIP attributes the $\$ 50$ change in the position over the period-from $\$ 200$ to $\$ 150$ - to a net outflow of $\$ 50$, when in fact the $\$ 50$ change in the position is due to a price change.

As shown in this analysis, the current omission of derivatives positions from the IIP adversely affects external-sector reporting and can lead to incorrect inferences about the cause of position changes in the IIP. In the IIP presented in the example, the failure to

4. Example of entries in the U.S. international investment position: Purchase by a foreign resident of a derivative from a U.S. resident, and subsequent sale of the derivative

U.S. dollars

\begin{tabular}{|c|c|c|c|c|c|c|c|}
\hline \multirow[b]{2}{*}{ Foreign-owned assets in the United States } & Year 0 & \multicolumn{3}{|c|}{ Year 1} & \multicolumn{3}{|c|}{ Year 2} \\
\hline & $\begin{array}{l}\text { Ending } \\
\text { balance }\end{array}$ & $\begin{array}{l}\text { Transaction } \\
\text { recorded in } \\
\text { BOP }\end{array}$ & $\begin{array}{c}\text { Valuation } \\
\text { adjustment }\end{array}$ & $\begin{array}{l}\text { Ending } \\
\text { balance }\end{array}$ & $\begin{array}{l}\text { Transaction } \\
\text { recorded in } \\
\text { BOP }\end{array}$ & $\begin{array}{c}\text { Valuation } \\
\text { adjustment }\end{array}$ & $\begin{array}{l}\text { Ending } \\
\text { balance }\end{array}$ \\
\hline U.S. financial derivatives liabilities ${ }^{1}$ & n.a. & n.a. & n.a. & n.a. & n.a. & n.a. & n.a. \\
\hline $\begin{array}{l}\text { U.S. liabilities reported by U.S. banks, } \\
\text { not included elsewhere ............... }\end{array}$ & 200 & -100 & 0 & 100 & 50 & 0 & 150 \\
\hline Total & 200 & -100 & 0 & 100 & 50 & 0 & 150 \\
\hline
\end{tabular}

1. Refer to table 2 , note 1 .

BOP U.S. balance of payments.

n.a. Not available. 
account for transactions in, and holdings of, derivatives contracts created two problems. First, it misrepresented the cross-border positions. At the end of year 1 , the true foreign position of $\$ 150$ ( $\$ 100$ plus the correct value of the derivative- $\$ 50$ ) was recorded as $\$ 100$. Second, the valuation adjustments in derivatives positions incorrectly appear as net foreign outflows of $\$ 50$. These problems can be resolved through the inclusion of specific information about cross-border derivatives transactions and positions in the IIP-the information collected on TIC form D.

\section{OVERVIEW OF TIC FORM D}

U.S. regulatory agencies have collected some information on derivatives holdings for many years in reports outside of the TIC system. However, the reports do not collect most of the information needed to include derivatives in the international transactions accounts. For example, the reported data have excluded cross-border transactions and have either excluded some cross-border positions-such as those between a parent firm and its cross-border affiliatesor collected positions on an ultimate-risk basis rather than a locational basis. ${ }^{11}$ As noted earlier, to address the gaps in data collection, the Treasury Department introduced TIC form D in 2005 to gather information on cross-border derivatives transactions and positions. ${ }^{12}$

\section{Information Collected}

TIC form D collects information on U.S. residents' derivatives contracts with foreign entities, including all foreign affiliates of U.S. multinational firms. It focuses on two values: (1) the amount for which a derivatives contract can be exchanged in a transaction as of the end of the quarter, referred to as the fair value, and (2) the sum of all derivatives transactions

11. The TIC forms collect data on cross-border transactions and positions on a locational basis, as is required for reporting in the international transactions accounts. In other words, counterparties are identified according to the country in which the immediate transactor is located or the country in which the position is booked, as transactions and positions are recorded in this way in the BOP and IIP. Other reports collect cross-border position information on an ultimate-risk basis. These reports identify counterparties according to the country in which the ultimate risk lies. For example, a claim against a subsidiary firm will be reported vis-à-vis the country of the parent to the subsidiary. For more information on the differences between data collected on a locational basis and data collected on an ultimate-risk basis, refer to Carol C. Bertaut, William L. Griever, and Ralph W. Tryon (2006), "Understanding U.S. Cross-Border Securities Data," Federal Reserve Bulletin, vol. 92, pp. A59-A75, www.federalreserve.gov/pubs/ bulletin/default.htm.

12. TIC form D and instructions for its use are available at www.treas.gov/tic/forms-d.shtml. that occur within the reporting quarter, including the proceeds from the purchases and sales of derivatives and all contractual flows, referred to as net settlements. ${ }^{13}$

As is the case on other regulatory reports, fair values on form $\mathrm{D}$ are aggregated according to whether, from the reporter's perspective, the value on the last day of the quarter is positive or negative. The gross positive (or negative) fair value is the sum of all positions with positive (or negative) balances from the perspective of the reporter. ${ }^{14}$

Along with fair values as of the end of the quarter, the net payments, or settlements, between the reporter and foreign residents in each quarter are reported on form D. All transactions occurring during each quarter, including those that arise from the purchases and sales of derivatives as well as from periodic contractual payments, are aggregated and reported as net settlements.

In part 1 of form $\mathrm{D}$, reporters provide totals by type of contract and type of underlying (table 5). Contracts that trade in the over-the-counter (OTC) market are reported separately from those that trade on exchanges. OTC contracts are categorized by the predominant type of underlying (that is, single-currency interest rate, foreign exchange, or other). ${ }^{15}$ Data on exchange-traded contracts are reported separately for U.S. reporting firms' own contracts on foreign exchanges, the contracts of their U.S. customers on foreign exchanges, and foreign counterparties' contracts on U.S. exchanges. The fair values of OTC derivatives are reported separately for common contract types (that is, forwards, swaps, or options), while only the aggregate fair values of all types of exchange-traded contracts (such as futures and options) are reported. Aggregate fair values are also

13. If a derivatives contract is not actively traded, the reporter must estimate the fair value using the prices of other financial instruments. Additional information on the calculation of fair values is available in Financial Accounting Standards Board (1998), "Statement of Financial Accounting Standards No. 133: Accounting for Derivative Instruments and Hedging Activities" (Norwalk, Conn.: FASB). For a discussion of why contractual payments on derivatives are included in the financial account instead of the current account, refer to box "Derivatives in the International Transactions Accounts."

14. Although reporters are encouraged to report fair values on a gross basis, the instructions state that multiple contracts with a single counterparty can be reported on a net basis if a master netting agreement is in place and if the contracts are carried at net values in the reporting entity's accounting records and statements of financial position. A master netting agreement is a contract between two counterparties to net their trades with positive and negative balances. This practice reduces credit exposure, which, in turn, reduces collateral requirements. To date, a limited number of TIC form D reporters have provided some of their fair values on a net basis.

15. Other underlying types include credit ratings, equity prices, and commodity prices. 
5. Data reported on TIC form D: U.S. holdings of, and transactions in, derivatives contracts with foreign residents, as of 2006:Q4

Millions of U.S. dollars

\begin{tabular}{|c|c|c|c|c|}
\hline \multirow{2}{*}{$\begin{array}{l}\text { Holdings and transactions, by contract type } \\
\text { and by foreign economies and organizations }\end{array}$} & \multicolumn{2}{|c|}{$\begin{array}{l}\text { Fair value of derivatives contracts with } \\
\text { foreign residents at end of reporting quarter }\end{array}$} & \multirow{2}{*}{$\begin{array}{l}\text { U.S. net settlements } \\
\text { during the quarter } \\
\text { with foreign residents }\end{array}$} & \multirow{2}{*}{$\begin{array}{l}\text { U.S. net settlements } \\
\text { during } 2006 \text { with } \\
\text { foreign residents }\end{array}$} \\
\hline & Gross positive & Gross negative & & \\
\hline \multicolumn{5}{|l|}{ PART I OF Form: CONTRACT Types } \\
\hline Over-the-counter contracts $\ldots \ldots \ldots \ldots \ldots \ldots \ldots$ & $1,211,924$ & $1,155,726$ & $-2,125$ & 14,553 \\
\hline Single-currency interest rate contracts . & 789,994 & 746,635 & $-2,543$ & 11,201 \\
\hline Forwards $\ldots \ldots \ldots \ldots \ldots \ldots \ldots$ & 1,747 & 1,622 & ... & $\ldots$ \\
\hline 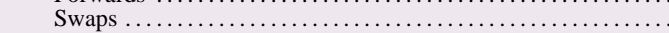 & 702,266 & 678,278 & $\ldots$ & $\ldots$ \\
\hline Options $\ldots \ldots \ldots \ldots \ldots$ & 85,981 & 66,735 & & \\
\hline Foreign exchange contracts & 175,713 & 150,272 & 142 & -211 \\
\hline Forwards ............... & 44,928 & 47,063 & . . . & $\ldots$ \\
\hline Swaps .... & 102,255 & 77,621 & $\ldots$ & \\
\hline 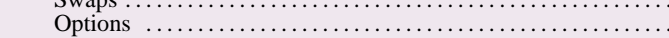 & 28,530 & 25,588 & $\cdots$ & $\cdots$ \\
\hline 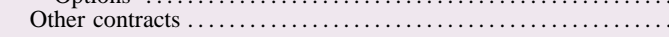 & 246,217 & 258,819 & 276 & 3,563 \\
\hline Exchange-traded contracts $\ldots$ & 25,640 & 22,903 & 342 & 14,209 \\
\hline Total on foreign exchanges $\ldots \ldots \ldots \ldots \ldots \ldots \ldots$ & 7,471 & 6,765 & 1,056 & 10,365 \\
\hline Own derivatives contracts on foreign exchanges $\ldots \ldots \ldots \ldots$ & 4,589 & 4,027 & 162 & 6,628 \\
\hline U.S. customers' derivatives contracts on foreign exchanges & 2,882 & 2,738 & 894 & 3,737 \\
\hline Foreign counterparty derivatives contracts on U.S. exchanges ... & 18,169 & 16,138 & -714 & 3,844 \\
\hline 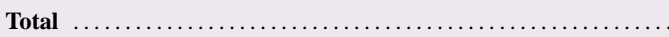 & $1,237,564$ & $1,178,629$ & $-1,783$ & 28,762 \\
\hline \multicolumn{5}{|l|}{ Мемо } \\
\hline Contracts with own foreign offices $\ldots \ldots$. & 318,987 & 312,853 & & \\
\hline Contracts with foreign official institutions ............. & 10,746 & 9,601 & 211 & 2,120 \\
\hline Contracts of U.S. depository institutions with foreigners & 415,979 & 397,523 & $\ldots$ & $\ldots$ \\
\hline \multicolumn{5}{|l|}{ PART 2 OF FORM: Foreign ECONOMIES AND ORGanizations } \\
\hline 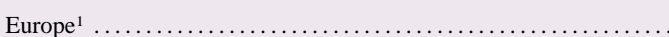 & $1,045,720$ & 993,391 & 147 & 19,855 \\
\hline Belgium & 9,881 & 9,291 & -15 & -315 \\
\hline France ... & 72,559 & 66,746 & -570 & 759 \\
\hline Germany & 97,243 & 85,356 & $-1,515$ & -687 \\
\hline Ireland .. & 80,219 & 77,926 & 340 & 4,415 \\
\hline Italy $\ldots . . .$. & 12,228 & 5,863 & -556 & 215 \\
\hline Netherlands & 23,396 & 21,280 & 439 & 1,914 \\
\hline Switzerland ....... & 29,412 & 28,054 & $-1,371$ & 4,849 \\
\hline United Kingdom & 697,207 & $\begin{array}{r}20,034 \\
668,332\end{array}$ & $\begin{array}{r}-1,511 \\
4,422\end{array}$ & $\begin{array}{l}4,049 \\
6,550\end{array}$ \\
\hline Euro area ........ & 308,976 & 286,459 & $-2,487$ & 9,158 \\
\hline European Union ... & $1,013,071$ & 962,042 & 2,068 & n.a. \\
\hline Canada ............. & 31,527 & 27,059 & 42 & $-4,507$ \\
\hline Latin America .......... & 14,346 & 13,299 & $-1,369$ & $-1,464$ \\
\hline Caribbean...$\ldots \ldots \ldots$. & 67,156 & 73,000 & -608 & 5,325 \\
\hline Cayman Islands & 49,661 & 57,345 & -705 & 4,840 \\
\hline Asia ............ & 58,723 & 53,938 & 102 & 5,862 \\
\hline Japan .......... & 39,075 & 37,568 & -933 & -346 \\
\hline Africa $\ldots \ldots \ldots$ & 3,085 & 2,153 & 243 & 610 \\
\hline Other countries & 14,294 & 11,173 & $-1,543$ & $-2,317$ \\
\hline Australia $\ldots \ldots \ldots \ldots \ldots \ldots \ldots \ldots \ldots$ & 13,369 & 10,444 & $-1,648$ & $-2,505$ \\
\hline International and regional organizations ${ }^{2}$. & 2,713 & 4,616 & 1,203 & 5,396 \\
\hline
\end{tabular}

1. Selection of economies listed in form.

2. Summation of organizations listed in form.

. Not applicable.

n.a. Not available.

SourCE: Treasury International Capital reporting system, www.treas.gov/tic.

reported for three memoranda items: contracts with the reporting firms' own foreign offices, contracts with foreign official institutions, and contracts of U.S. depository institutions with foreigners. In part 2 of form D, fair values and net settlements are reported in aggregate by the counterparty's country of residence.

For many OTC contracts, cash flows are few or even nonexistent during a quarter, while fair values are significant. For those exchange-traded products (such as futures) that settle daily, the fair value is at most the change in value on the last day of the quarter, and so it will generally be quite small. The difference between net settlements and fair values for exchange-traded products will generally be smaller than the corresponding difference for OTC contracts,

as net settlements for exchange-traded products include the sum of all the daily changes in the value of a contract over the quarter.

\section{Reporting Threshold and Requirements}

The reporting threshold used to determine who must file TIC form D is based on a common measure of the size of total derivatives positions, the notional value, defined earlier in the article as an amount used to determine contractual payments. All U.S. banks, securities dealers, and other firms with worldwide holdings of derivatives exceeding $\$ 100$ billion in notional value (in their own and their customers' accounts) are required to fill out form $\mathrm{D}$ on a quarterly basis. The 


\section{Derivatives in the International Transactions Accounts}

Derivatives do not fit neatly into the international transactions accounts for two reasons. The first is that, unlike financial instruments such as bonds and stocks, some derivatives contracts cannot be categorized solely as claims or liabilities. Clearly an option written by a U.S. resident and purchased by a foreign resident is a U.S. liability to foreigners; but the distinction is less clear for products such as swaps, forwards, and futures. Over the lives of these products, the fair market value may be positive at times and negative at times, and it may switch signs several times within a quarter. So these instruments are neither strictly claims, with consistently positive fair values and payments to the U.S. resident counterparty to the contract, nor strictly liabilities, with consistently negative fair values and payments from the U.S. resident counterparty.
The second reason that derivatives are not easily incorporated into the international transactions accounts is the ambiguous status of the associated payments. The periodic payments on derivatives can be considered returns on invested capital, which are recorded in the current account; alternatively, they can be considered realized gains from changes in the contractual value, which are recorded in the financial account. Because the return from derivatives for many end users comes in the form of trading gains and losses, the International Monetary Fund has recommended that periodic payments on derivatives be recorded as financial account transactions. ${ }^{1}$

1. Refer to Robert M. Heath (1998), "The Statistical Measurement of Financial Derivatives," IMF Working Paper 98/24 (Washington: International Monetary Fund, March). reporting threshold was intentionally set at a high level because, according to results obtained by other forms that collect global derivatives information, derivatives activity is concentrated in a small number of firms; fifty companies met the threshold in 2006. Forms are filed with, and validated by, the Federal Reserve Bank of New York. After further evaluation by the Federal Reserve Board, results are forwarded to the Treasury Department for release to the public.

To ease the burden on reporters, reporting requirements for form $\mathrm{D}$ were phased in over the first three quarters of 2005. In the first quarter, reporters were required to provide all categories of gross positive and gross negative fair values, net settlements of OTC foreign exchange contracts, and net settlements with foreign official institutions. In the second quarter, net settlements of exchange-traded contracts were added to the requirements. Finally, in the third quarter, all remaining information was required.

\section{TIC Form D and Reporting on the U.S. External Sector}

Starting in mid-2007, the compilers of the financial account at the BEA will have access to information from TIC form D on transactions and positions in cross-border derivatives. Unlike other financial instruments, derivatives do not fit easily into the standard BOP and IIP frameworks. For example, some derivatives contracts are difficult to classify strictly as claims or liabilities (refer to box "Derivatives in the International Transactions Accounts"). Because of this difficulty, in the international transactions accounts, the gross positive fair value will be recorded as the claims position, the gross negative fair value as the liabilities position, and net settlements as the net of claims and liabilities transactions.

To show how the information collected on form $\mathrm{D}$ will be used in the BOP and IIP, we return to the second example, in which a foreign resident purchases a derivative from a U.S. resident for $\$ 100$ in year 1 . Recall that the value decreases to $\$ 50$, and the foreign resident sells the derivative for $\$ 50$ in year 2 . As shown previously, without the information collected on form $\mathrm{D}$, at the end of year 1 the banking transaction corresponding to the payment of $\$ 100$ for the derivatives contract is included in the BOP as a decrease in U.S. bank liabilities to foreigners, but the offsetting transaction corresponding to the increased U.S. derivatives liabilities to foreigners is not recorded in the accounts; rather, it appears as a statistical discrepancy. When the derivative is sold, there is an increase of $\$ 50$ in U.S. bank liabilities to foreigners but no offsetting decrease in U.S. derivatives liabilities to foreigners, and so another statistical discrepancy is recorded.

That situation will change once the net settlements data collected on form $\mathrm{D}$ are incorporated into the BOP. Because the purchase price of the derivative $(\$ 100)$ and the sale proceeds $(\$ 50)$ will be included in net settlements on the U.S. resident's form $\mathrm{D}$ reports, the compilers of the financial account will have the information needed to include derivatives transactions in that account (table 6). The transactions will be correctly recorded in years 1 and 2 , and no statistical discrepancy will be reported in either year. 
6. Example of entries, including those for derivatives data, in the financial account of the U.S. balance of payments: Purchase by a foreign resident of a derivative from a U.S. resident, and subsequent sale of the derivative U.S. dollars

\begin{tabular}{|c|c|c|}
\hline \multirow{2}{*}{ Foreign-owned assets in the United States } & \multicolumn{2}{|c|}{ Financial flow } \\
\hline & Year 1 & Year 2 \\
\hline U.S. financial derivatives liabilities ${ }^{1} \ldots$ & 100 & -50 \\
\hline $\begin{array}{l}\text { U.S. liabilities reported by U.S. banks, } \\
\text { not included elsewhere ............... }\end{array}$ & -100 & 50 \\
\hline Statistical discrepancy $\ldots \ldots \ldots \ldots \ldots$ & 0 & 0 \\
\hline
\end{tabular}

1. Refer to table 2 , note 1 .

The fair values and transaction information collected on form $\mathrm{D}$ will also enable the compilers of the IIP to include derivatives contracts. The purchase price of the derivative $(\$ 100)$ and the year-end fair value (\$50) will be included in the IIP for year 1 , and the decrease in the total value of foreign assets from $\$ 200$ to $\$ 150$ will be correctly attributed to the price change of the derivative (table 7). The position at the start of year 2 will be correctly reported, as will the transactions in that year. As shown in this example, the information collected on form D substantially improves the reporting of both the BOP and the IIP.

\section{RESULTS FROM THE 2006 FORM D DATA}

The Treasury Department recently released aggregate values of the data reported on TIC form D in 2006. In December 2006, the gross positive fair value of derivatives totaled $\$ 1.238$ trillion, and the gross negative fair value $\$ 1.179$ trillion (table 5, row labeled "Total"). Data for December 2006 are representative of broader trends for the year as a whole in terms of the relative magnitudes of the fair values reported in each category of form D. The largest fair values are for OTC derivatives, primarily single-currency interest rate swaps. The fair values reported for exchangetraded derivatives are much smaller. As discussed previously, this result is expected because exchange- traded futures that settle daily account for the bulk of exchange-traded derivatives; for these products, the fair values generally consist entirely of one-day market moves. For most types of derivatives, the reported gross positive fair value exceeds the reported gross negative fair value. Therefore, residents of the United States have net derivatives claims on foreign residents.

Unlike fair values, reported net settlements vary widely between quarters, and the flows associated with both OTC and exchange-traded derivatives are significant. During the fourth quarter of 2006, total net settlements represented a $\$ 1.783$ billion outflow from the United States, primarily associated with single-currency interest rate products (table 5, row labeled "Total"). However, the result over the previous three quarters was quite different: a net inflow to residents of the United States, also primarily from single-currency interest rate products. So for all of 2006 , net settlements represented a $\$ 28.8$ billion inflow to the United States. The amount was evenly split between inflows associated with OTC contracts and those associated with exchange-traded contracts.

As with other TIC data on securities and banking, the bulk of fair values and net settlements is vis-à-vis the United Kingdom, but large balances are also recorded against other European countries, the Caribbean financial center countries (such as the Cayman Islands), and Japan. ${ }^{16}$ In December 2006, the gross positive fair value of derivatives vis-à-vis residents of the United Kingdom totaled $\$ 697$ billion, while the gross negative fair value totaled $\$ 668$ billion, each of which represented more than half of the total reported gross fair values (table 5, row labeled "United King-

\footnotetext{
16. Because TIC transactions are recorded against the country through which the transaction occurred, the data exhibit "financial center bias"; in other words, a majority of transactions are recorded vis-à-vis countries in which many financial services firms active in the derivatives market are located. For more information on the issue of financial center bias in TIC data, refer to Bertaut, Griever, and Tryon, "Understanding U.S. Cross-Border Securities Data."
}

7. Example of entries, including those for derivatives data, in the U.S. international investment position: Purchase by a foreign resident of a derivative from a U.S. resident, and subsequent sale of the derivative

U.S. dollars

\begin{tabular}{|c|c|c|c|c|c|c|c|}
\hline \multirow[b]{2}{*}{ Foreign-owned assets in the United States } & Year 0 & \multicolumn{3}{|c|}{ Year 1} & \multicolumn{3}{|c|}{ Year 2} \\
\hline & $\begin{array}{l}\text { Ending } \\
\text { balance }\end{array}$ & $\begin{array}{l}\text { Transaction } \\
\text { recorded in } \\
\text { BOP }\end{array}$ & $\begin{array}{c}\text { Valuation } \\
\text { adjustment }\end{array}$ & $\begin{array}{l}\text { Ending } \\
\text { balance }\end{array}$ & $\begin{array}{c}\text { Transaction } \\
\text { recorded in } \\
\text { BOP }\end{array}$ & $\begin{array}{c}\text { Valuation } \\
\text { adjustment }\end{array}$ & $\begin{array}{l}\text { Ending } \\
\text { balance }\end{array}$ \\
\hline U.S. financial derivatives liabilities ${ }^{1} \ldots$ & 0 & 100 & -50 & 50 & -50 & 0 & 0 \\
\hline $\begin{array}{l}\text { U.S. labilities reported by U.S. banks, } \\
\text { not included elsewhere .............. }\end{array}$ & 200 & -100 & 0 & 100 & 50 & 0 & 150 \\
\hline Total & 200 & 0 & -50 & 150 & 0 & 0 & 150 \\
\hline
\end{tabular}

1. Refer to table 2, note 1 .

BOP U.S. balance of payments. 
8. Effect of derivatives data on the statistical discrepancy in the international transactions accounts of the U.S. balance of payments, by quarter, 2006

Billions of U.S. dollars

\begin{tabular}{|c|c|c|c|c|c|}
\hline \multirow{2}{*}{ Account } & \multicolumn{5}{|c|}{ Financial flow } \\
\hline & 2006 & Q1 & Q2 & Q3 & Q4 \\
\hline Scenario A (without derivatives) & & & & & \\
\hline Current account $\ldots \ldots \ldots \ldots \ldots$ & -857 & -214 & -218 & -229 & -196 \\
\hline Capital account ............. & -4 & -2 & -1 & -1 & -1 \\
\hline Financial account ... & 719 & 171 & 154 & 230 & 165 \\
\hline Total $\ldots \ldots \ldots \ldots$ & -141 & -44 & -65 & 0 & -32 \\
\hline Statistical discrepancy & 141 & 44 & 65 & 0 & 32 \\
\hline Scenario B (with derivatives) & & & & & \\
\hline Current account......... & -857 & -214 & -218 & -229 & -196 \\
\hline Capital account...$\ldots \ldots$. & -4 & -2 & -1 & -1 & -1 \\
\hline Financial account ......... & 719 & 171 & 154 & 230 & 165 \\
\hline Derivatives $\ldots \ldots \ldots \ldots \ldots$ & 29 & 2 & 14 & 15 & -2 \\
\hline Total $\ldots \ldots \ldots \ldots$ & -113 & -43 & -51 & 15 & -34 \\
\hline Statistical discrepancy . & 113 & 43 & 51 & -15 & 34 \\
\hline
\end{tabular}

Note: Components may not sum to totals because of rounding. Data for financial derivatives represent net settlements as reported on TIC form D.

Source: Bureau of Economic Analysis, "U.S. International Transactions," www.bea.gov/international; and TIC form D.

dom"). Net settlements vis-à-vis U.K. residents totaled $\$ 4.4$ billion during the fourth quarter of 2006 and $\$ 6.6$ billion for all of 2006, the largest flows (in absolute magnitude) into or out of any single country.

\section{The 2006 Data in the BOP and IIP}

The important role played by cross-border derivatives in U.S. financial markets becomes apparent when the TIC form D aggregates are compared with the transactions and positions in other financial instruments recorded in the international transactions accounts in 2006. Derivatives transactions reported on form D varied substantially throughout 2006, ranging from a $\$ 15$ billion inflow in the third quarter to a $\$ 2$ billion outflow in the fourth quarter (table 8, row labeled "Derivatives"). This variability is typical of crossborder flows in securities such as stocks and bonds. For 2006, derivatives net settlements amounted to inflows of $\$ 29$ billion, or 4 percent of the $\$ 719$ billion in total financial inflows reported in the BOP.

Derivatives net settlements appear more significant when they are compared with the magnitude of the statistical discrepancy. As shown in previous examples, if the international transactions accounts contained no errors or omissions except the omission of derivatives, the inclusion of derivatives data would reduce the BOP statistical discrepancy to zero. Although including the 2006 data on total form D net settlements in the BOP would not erase the statistical discrepancy, it would reduce it in that year. ${ }^{17}$ For 2006, the statistical discrepancy totaled $\$ 141$ billion

17. Because, as previously discussed, some derivatives transactions are already included in the international transactions accounts, this
9. Net international investment position of the United States and selected components, and aggregate fair values of derivatives, year-end 2005

Billions of U.S. dollars

\begin{tabular}{|c|c|}
\hline Item & Amount \\
\hline Net position & $-2,694$ \\
\hline U.S.-owned assets abroad & 10,009 \\
\hline 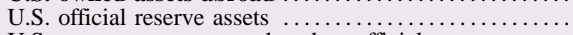 & 188 \\
\hline U.S. government assets other than official reserve assets & 78 \\
\hline 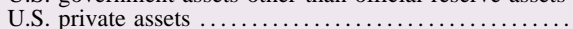 & 9,743 \\
\hline Direct investment abroad (current cost) & 2,454 \\
\hline Foreign securities $\ldots \ldots \ldots \ldots \ldots \ldots \ldots$ & 4,074 \\
\hline Bonds ........... & 988 \\
\hline Corporate stocks ................................... & 3,086 \\
\hline U.S. claims on unaffiliated foreigners reported & \\
\hline $\begin{array}{l}\text { by U.S. nonbanking concerns } \ldots \ldots \ldots \ldots \ldots \\
\text { U.S. claims reported by U.S. banks. }\end{array}$ & 785 \\
\hline 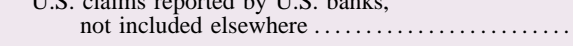 & 2,431 \\
\hline Foreign-owned assets in the United States & 12,702 \\
\hline Foreign official assets in the United States .. & 2,216 \\
\hline Other foreign assets ................... & 10,486 \\
\hline Direct investment in the United States (current cost) & 1,874 \\
\hline U.S. Treasury securities …................... & 705 \\
\hline U.S. securities other than U.S. Treasury securities & 4,391 \\
\hline Corporate and other bonds $\ldots \ldots \ldots \ldots \ldots \ldots$ & 2,275 \\
\hline Corporate stocks ........... & 2,115 \\
\hline 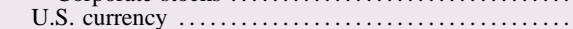 & 352 \\
\hline $\begin{array}{l}\text { U.S. liabilities to unaffiliated foreigners reported } \\
\text { by U.S. nonbanking concerns }\end{array}$ & 564 \\
\hline 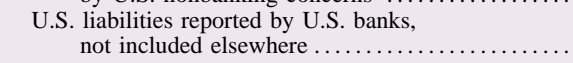 & 2,601 \\
\hline Aggregate fair values of derivatives & \\
\hline Gross positive ................... & 1,190 \\
\hline Gross negative . & 1,132 \\
\hline
\end{tabular}

SouRCE: For net international investment position, Bureau of Economic Analysis (2006), Survey of Current Business, vol. 86 (July), table 1, pp. 9-19; for aggregate fair values, TIC form D.

(table 8, scenario A); the inclusion of derivatives net settlements in the BOP would have lowered the discrepancy roughly 20 percent (table 8 , scenario B). ${ }^{18}$ As the quarterly data show, the effect of derivatives on the statistical discrepancy may vary from quarter to quarter and year to year, as errors and omissions elsewhere in the international transactions accounts may outweigh the effect of derivatives.

The U.S. gross positions in derivatives are comparable in magnitude with the U.S. positions in other financial instruments (table 9). The gross positive fair value of derivatives totaled $\$ 1,190$ billion at the end of 2005, slightly more than U.S. residents' holdings of foreign bonds, which totaled $\$ 988$ billion. The gross negative fair value of derivatives totaled $\$ 1,132$ billion, about half of foreign holdings of U.S. bonds or stocks. On net, however, the inclusion of derivatives has little effect on the net international investment position of the United States. Adding the net position in derivatives of $\$ 58$ billion (aggregate

estimate is only a rough approximation of the effect of derivatives data on the statistical discrepancy in the BOP financial account.

18. For a discussion of other possible sources of the statistical discrepancy, refer to Norman S. Fieleke (1996), "What Is the Balance of Payments?" Special Report No. 3 (Boston: Federal Reserve Bank of Boston, October), www.bosfed.org/economic/special/balofpay.pdf. 


\section{Other Derivatives Reports}

As discussed in the main text, TIC form D was developed because most of the information necessary to include derivatives in the U.S. balance of payments and the U.S. international investment position was not captured on other reports. For example, most of the existing derivatives forms require firms to provide consolidated exposure to both domestic and foreign counterparties. Although the information collected on these other forms is not exactly comparable with that collected on form D, it is useful for data verification at the firm and product levels.

One form with data on global derivatives holdings is the FR Y-9C ("Consolidated Financial Statements for Bank Holding Companies," prepared by the Federal Reserve Board), which is required of bank holding companies; the data are publicly available and are used by the Office of the Comptroller of the Currency in its Bank Derivatives Quarterly Report. For U.S. branches of foreign banks, similar information is collected on form FFIEC 002 ("Report of Assets and Liabilities of U.S. Branches and Agencies of Foreign Banks," prepared by the Federal Financial Institutions Examination Council, or FFIEC). Another form that requests data on derivatives' fair values is the FR 2436 ("Semiannual Report of Derivatives Activity," prepared by the Federal Reserve Board), which collects information on gross positions in over-the-counter (OTC) derivatives from the largest U.S. bank and nonbank dealers. The reported results are confidential, and aggregates are forwarded to the Bank for International Settlements, which consolidates them with results from other global reporters for publication in its quarterly Consolidated Bank Statistics and in other of its reports, such as the Regular OTC Derivatives Market Statistics.

Although cross-border derivatives are included in the totals, most of the existing derivatives forms do not require separate reporting of cross-border derivatives. The few reports that do separately report the cross-border exposure, like the FFIEC 009 ("Country Exposure Report," prepared by the FFIEC), collect it on an ultimaterisk basis instead of the locational basis required for reporting in the international transactions accounts. ${ }^{1}$

Whereas holdings are included in some form on other reports, no report other than TIC form D collects payments information for OTC derivatives. For exchangetraded derivatives, however, net settlements are often equivalent to net trading profits and losses (excluding commissions). Because reporters already provided such profits and losses to the U.S. tax authorities, existing systems could be adapted to fulfill form $\mathrm{D}$ requirements.

1. An exception is the Commodity Futures Trading Commission's form 40, which collects daily position data on futures and futures options from the largest traders on U.S. exchanges. The information includes the trader's country of residence. The Bureau of Economic Analysis has used this information in compiling the U.S. balance of payments and the U.S. international investment position. gross positive fair value minus aggregate gross negative fair value) only slightly improves the U.S. net international investment position, from negative $\$ 2,694$ billion to negative $\$ 2,636$ billion.

\section{Comparison of U.S. and Foreign Aggregate Totals}

From a global perspective, a relationship exists between the cross-border transactions into and out of the United States and those into and out of other countries. Many other countries currently report derivatives transactions and positions separately on their balance of payments and international investment position. If all countries were to report crossborder transactions accurately and on the same basis, then the summation of all cross-border flows in each asset class into and out of all countries would equal zero. That is, the derivatives outflows from one country should be recorded as derivatives inflows to other countries. The same relationship holds for positions: The sum across countries of net cross-border positions in each asset class should equal zero. Such comparisons of international flows and positions represent two checks at the macro level on the reason- ableness of the information reported on form $\mathrm{D}$, and they complement the cross-checks performed at the micro level by the Federal Reserve Bank of New York (refer to box "Other Derivatives Reports"). ${ }^{19}$

A comparison of aggregate form D net settlements with the cross-border transactions and positions reported by other countries suggests that U.S. residents are counterparties to a significant share of the transactions in the global cross-border derivatives market. Total U.S. transactions as reported on form D were larger in absolute value than those reported by any other country in 2006 (table 10). In 2005 and 2006, all other countries recorded a net derivatives outflow, while in 2006 the United States recorded a net inflow. The recorded net derivatives inflow into the United

19. Countries other than the United States, including Australia and the United Kingdom, have reported problems with the collection and quality of cross-border derivatives data. Refer to Graham Semken (2005), "Financial Derivatives in the UK Sector Balance Sheets and Financial Accounts," Economic Trends, vol. 618 (May), pp. 37-44; and Australian Bureau of Statistics, International and Financial Accounts Branch (1998), "Financial Derivatives in Australia's International Accounts," paper prepared for the Eleventh Meeting of the IMF Committee on Balance of Payments Statistics, held at the International Monetary Fund, Washington, Oct. 21-23, www.imf.org/ external/bopage/agenda.htm. 
10. Aggregate cross-border derivatives transactions for selected foreign countries, the United States, and the world, 2005-06

Billions of U.S. dollars

\begin{tabular}{|c|c|c|c|c|c|c|}
\hline \multirow{2}{*}{ Country or area } & \multirow{2}{*}{2005} & \multirow{2}{*}{2006} & \multicolumn{4}{|c|}{2006} \\
\hline & & & Q1 & Q2 & Q3 & Q4 \\
\hline Australia & -1.6 & .5 & -.2 & .6 & -.5 & .6 \\
\hline Denmark & 1.7 & 2.8 & 1.2 & .4 & .3 & .9 \\
\hline France $\ldots .$. & 9.9 & 4.3 & 1.1 & 3.0 & 2.2 & -2.0 \\
\hline Hong Kong & 4.0 & 5.1 & .3 & 1.9 & 1.1 & 1.8 \\
\hline Italy ....... & 3.1 & -1.6 & .3 & .4 & -1.8 & -.5 \\
\hline Japan ..... & -6.6 & 2.0 & -.4 & 1.8 & -.1 & .7 \\
\hline Netherlands & -4.4 & -7.1 & -2.8 & -.6 & -1.6 & -2.1 \\
\hline United Kingdom & -4.4 & -26.2 & -10.5 & -5.3 & -7.6 & -2.8 \\
\hline United States ....... & n.a. & 28.8 & 1.6 & 14.0 & 14.9 & -1.8 \\
\hline World excluding the & & & & & & \\
\hline United States .. & -22.5 & -23.0 & -18.4 & .6 & -1.8 & -3.4 \\
\hline World $\ldots \ldots \ldots \ldots$ & -22.5 & 5.8 & -16.8 & 14.6 & 13.1 & -5.2 \\
\hline
\end{tabular}

NoTE: Components may not sum to totals because of rounding. Net flows reported in balance of payments statistics. World totals include flows of countries not shown.

n.a. Not available.

SOURCE: For selected foreign countries and the world, individual country pages of the IMF website, www.imf.org; for the United States, TIC form D.

States in 2006 ( $\$ 28.8$ billion) is similar in magnitude to the sum of the outflows reported by all other countries (negative $\$ 23.0$ billion). Although on a quarterly basis the inclusion of U.S. derivatives transactions in the calculation of net world transactions resulted in values that varied considerably from zero, for the year as a whole it resulted in a value much closer to zero, an indication that U.S. data from TIC form D will significantly reduce the gap in world accounting in the BOP. ${ }^{20}$

A comparison of U.S. aggregate derivatives claims and liabilities with those of other countries further shows the sizable role played by the United States in the global derivatives market. In 2005 U.S. derivatives claims and liabilities, approximated using the gross positive and gross negative fair values on form $\mathrm{D}$, were greater than those reported by all countries except the United Kingdom (table 11). On a net basis, the U.S. year-end derivatives position for 2005 was a net claim of $\$ 58$ billion. This U.S. net claim is similar in magnitude and opposite in sign to the sum of the net derivatives positions reported by all other countries, which is a $\$ 55$ billion liability. As with transactions, including the U.S. position in the

20. This analysis is incomplete, however, because some countries and organizations with significant flows vis-à-vis the United States do not report cross-border transactions (for example, Caribbean financial center countries, Switzerland, and the Bank for International Settlements).

11. Aggregate cross-border derivatives claims and liabilities, and net positions in derivatives, for selected foreign countries, the United States, and the world, 2000-05

Billions of U.S. dollars

\begin{tabular}{|c|c|c|c|c|c|c|c|c|c|c|c|}
\hline Year & Australia & Denmark & France & $\begin{array}{l}\text { Hong } \\
\text { Kong }\end{array}$ & Italy & Japan & Netherlands & $\begin{array}{l}\text { United } \\
\text { Kingdom }\end{array}$ & $\begin{array}{l}\text { United } \\
\text { States }\end{array}$ & $\begin{array}{l}\text { World } \\
\text { excluding } \\
\text { the United } \\
\text { States }\end{array}$ & World \\
\hline & \multicolumn{11}{|c|}{ Claims } \\
\hline $\begin{array}{l}2000 \ldots \\
2001 \ldots \\
2002 \ldots \\
2003 \ldots \\
2004 \ldots \\
2005 \ldots\end{array}$ & $\begin{array}{l}13 \\
15 \\
20 \\
33 \\
38 \\
27 \\
\end{array}$ & $\begin{array}{r}14 \\
11 \\
31 \\
24 \\
37 \\
9 \\
\end{array}$ & $\begin{array}{r}95 \\
110 \\
108 \\
136 \\
169 \\
226 \\
\end{array}$ & $\begin{array}{l}17 \\
18 \\
23 \\
20 \\
22 \\
17 \\
\end{array}$ & $\begin{array}{r}4 \\
4 \\
11 \\
23 \\
28 \\
30 \\
\end{array}$ & $\begin{array}{r}3 \\
3 \\
3 \\
5 \\
6 \\
26 \\
\end{array}$ & $\begin{array}{l}29 \\
45 \\
72 \\
87 \\
86 \\
70 \\
\end{array}$ & $\begin{array}{r}669 \\
858 \\
1,245 \\
1,393 \\
1,594 \\
1,761 \\
\end{array}$ & $\begin{array}{c}\text { n.a. } \\
\text { n.a. } \\
\text { n.a. } \\
\text { n.a. } \\
\text { n.a. } \\
1,190\end{array}$ & $\begin{array}{r}876 \\
1,101 \\
1,562 \\
1,803 \\
2,087 \\
2,262 \\
\end{array}$ & $\begin{array}{r}876 \\
1,101 \\
1,562 \\
1,803 \\
2,087 \\
3,452 \\
\end{array}$ \\
\hline 2005 . & \multicolumn{11}{|c|}{ Liabilities } \\
\hline $\begin{array}{l}2000 \ldots \\
2001 \ldots \\
2002 \ldots \\
2003 \ldots \\
2004 \ldots \\
2005 \ldots\end{array}$ & $\begin{array}{l}13 \\
13 \\
21 \\
37 \\
38 \\
28 \\
\end{array}$ & $\begin{array}{r}13 \\
11 \\
28 \\
20 \\
33 \\
0 \\
\end{array}$ & $\begin{array}{r}98 \\
105 \\
112 \\
148 \\
175 \\
243 \\
\end{array}$ & $\begin{array}{l}13 \\
12 \\
21 \\
20 \\
21 \\
17 \\
\end{array}$ & $\begin{array}{r}3 \\
5 \\
9 \\
16 \\
26 \\
38 \\
\end{array}$ & $\begin{array}{r}3 \\
4 \\
4 \\
7 \\
11 \\
33 \\
\end{array}$ & $\begin{array}{l}24 \\
49 \\
87 \\
95 \\
99 \\
87 \\
\end{array}$ & $\begin{array}{r}674 \\
861 \\
1,259 \\
1,424 \\
1,624 \\
1,780 \\
\end{array}$ & $\begin{array}{l}\text { n.a. } \\
\text { n.a. } \\
\text { n.a. } \\
\text { n.a. } \\
\text { n.a. } \\
1,132\end{array}$ & $\begin{array}{r}869 \\
1,088 \\
1,579 \\
1,848 \\
2,132 \\
2,317 \\
\end{array}$ & $\begin{array}{r}869 \\
1,088 \\
1,579 \\
1,848 \\
2,132 \\
3,449 \\
\end{array}$ \\
\hline 2005 . & \multicolumn{11}{|c|}{ Net position (claims less liabilities) } \\
\hline $\begin{array}{l}2000 \ldots \\
2001 \ldots \\
2002 \ldots \\
2003 \ldots \\
2004 \ldots \\
2005 \ldots\end{array}$ & $\begin{array}{r}-1 \\
2 \\
-1 \\
-3 \\
0 \\
-1\end{array}$ & $\begin{array}{l}1 \\
0 \\
2 \\
3 \\
4 \\
9\end{array}$ & $\begin{array}{r}-3 \\
5 \\
-4 \\
-11 \\
-6 \\
-17\end{array}$ & $\begin{array}{l}4 \\
5 \\
1 \\
0 \\
1 \\
0\end{array}$ & $\begin{array}{r}1 \\
0 \\
2 \\
7 \\
2 \\
-8\end{array}$ & $\begin{array}{r}0 \\
-1 \\
0 \\
-2 \\
-5 \\
-7\end{array}$ & $\begin{array}{r}5 \\
-5 \\
-15 \\
-8 \\
-13 \\
-17\end{array}$ & $\begin{array}{r}-5 \\
-3 \\
-14 \\
-32 \\
-30 \\
-19\end{array}$ & $\begin{array}{l}\text { n.a. } \\
\text { n.a. } \\
\text { n.a. } \\
\text { n.a. } \\
\text { n.a. } \\
\quad 58\end{array}$ & $\begin{array}{r}7 \\
13 \\
-17 \\
-45 \\
-45 \\
-55\end{array}$ & $\begin{array}{r}7 \\
13 \\
-17 \\
-45 \\
-45 \\
3\end{array}$ \\
\hline
\end{tabular}

Note: Components may not sum to totals because of rounding. World totals include positions of countries not shown. U.S. claims are aggregate gross positive fair values, and U.S. liabilities are aggregate gross negative fair values. The claims and liabilities positions of some countries include values reported on a net basis. For countries other than the United States, data on cross-border claims, liabilities, and net positions for year-end 2006 were not available as of the publication date.

n.a. Not available.

SourCE: For selected foreign countries (except the United Kingdom) and the world, International Monetary Fund, Balance of Payments Statistics Yearbook 2006 (Washington: IMF); for the United Kingdom, Office of National Statistics (2006), United Kingdom Balance of Payments: The Pink Book 2006 (New York: Palgrave Macmillan), table FD, p. 114; for the United States, TIC form D. 


\section{Implied Valuation Change}

The information on TIC form D can be used to estimate exposure to the underlyings through calculation of the valuation change implied by quarter-end movements in the fair values and net settlements. Specifically, the change in net fair value (gross positive fair value minus gross negative fair value) between two consecutive reporting quarters is the result of the combination of cash flows and valuation changes due to underlying price movements. That is, aside from the effect of trading activity, the following accounting relationship must hold:

$$
\begin{aligned}
& \text { Net fair value }(\text { start })+\text { Valuation changes }= \\
& \text { Net fair value }(\text { end })+\text { Net payments received } \text {. }
\end{aligned}
$$

In addition to measuring exposure, if the implied valuation changes are too large, they signal possible misreporting on form $\mathrm{D}$. Because the magnitude of valuation changes can vary with the number and value of positions, dividing each valuation change by a scaling factor such as the average of gross positive fair values at the start and end of the quarter assists in error identification.

The following example shows how implied valuation change can be used to identify exposure to the underlying and errors in reported net settlements and fair values. A U.S. resident has one swap contract with a foreign counterparty. The fair value of the swap is $\$ 100$, due the U.S. resident at time 1 (refer to table). Between time 1 and time 2, the U.S. resident receives a $\$ 20$ payment, and, if the price does not change, the fair value of the swap at time 2 is $\$ 80$. If everything is reported correctly on form $\mathrm{D}$, the implied valuation change is zero (scenario A). ${ }^{1}$ But if net settlements are erroneously reported as $\$ 150$, the implied valuation change is $\$ 130$ (scenario $\mathrm{B}$ ); if that value is divided by the average gross positive fair value, the scaled implied valuation change is 144 percent. $^{2}$ Alternatively, if the gross positive fair value at time 2 is erroneously reported as $\$ 20$, the implied valuation change is negative $\$ 60$, which corresponds to a scaled implied

1. The implied valuation change is $\$ 80-\$ 100+\$ 20=\$ 0$.

2 . The implied valuation change is $\$ 80-\$ 100+\$ 150=\$ 130$; the scaled implied valuation change is $\$ 130 /[(\$ 100+\$ 80) / 2]=1.44$, or 144 percent.
Example of the use of implied valuation change to identify errors in the net settlements and net fair values reported on TIC form D

U.S. dollars except as noted

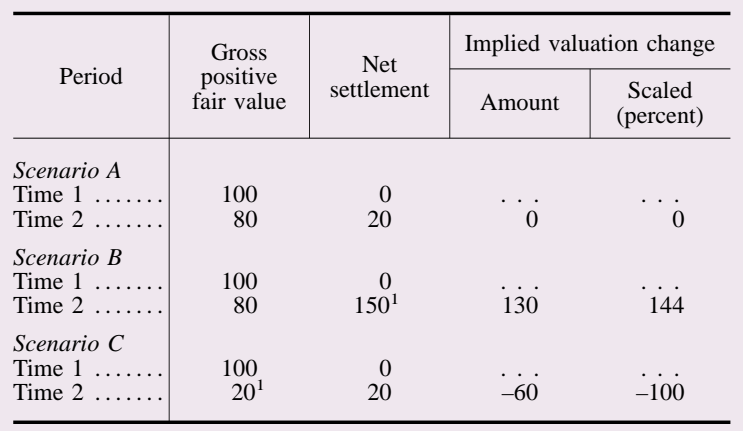

1. Erroneously reported. Not applicable.

valuation change of negative 100 percent (scenario C). ${ }^{3}$ In scenarios B and C, a high absolute value for the scaled implied valuation change signifies a reporting error.

The effectiveness of implied valuation change as an error-identification tool depends on the number of purchases and sales of derivatives and on movements in the underlyings. At one extreme, given no changes in a reporter's derivatives contracts and on market moves in the underlying prices, the valuation changes should be small; in such cases, the calculation of large implied valuation changes will effectively indicate the presence of an error. At the other extreme, given significant purchases or sales of derivatives or high volatility in the underlying markets, relating the implied valuation change to the movements in the underlyings will be difficult, and thus this methodology will be less effective at identifying errors.

3. The implied valuation change is $\$ 20-\$ 100+\$ 20=-\$ 60$. If the implied valuation change is divided by the average of the gross positive fair values, the scaled implied valuation change is $-\$ 60 /[(\$ 100+\$ 20) / 2]$ $=-1.00$, or -100 percent calculation of the net world position moves the world position closer to zero.

\section{USING THE DATA TO ESTIMATE RISK EXPOSURE}

Form D data can be used to estimate two types of risk exposure of interest to users of the data. The first type concerns the potential losses incurred if counterparties fail to fulfill their obligations, usually referred to as credit exposure. The data can be used to estimate an upper bound on cross-border credit exposure as of the report date. Because the total gross positive fair value is the sum of the fair values of all claims with a positive balance from the reporters' perspective, it is the maximum loss that would be sustained if foreign counterparties defaulted on their obligations. ${ }^{21}$ In practice, most of these positions are covered by legally enforceable netting agreements. In such cases, in the event of a counterparty default, positions with a counterparty that have positive fair values are reduced by the value of positions with the same counterparty that have negative fair values. As a result, the actual

21. An estimate of cross-border credit exposure should exclude those positions with affiliates, also reported on TIC form D. 
credit exposure is much less than would be implied by the gross positive fair value. Similarly, the gross fair value vis-à-vis foreign residents of a given country is somewhat indicative of the maximum credit exposure of U.S. residents to residents of that country. However, because all TIC data are reported on a locational basis rather than an ultimate-risk basis, the true nationality of counterparty exposure is unknown.

Another type of risk exposure of interest to users of the form D data concerns U.S. investors' potential losses or gains from changes in certain underlyings, such as exchange rates or interest rates, referred to as market exposure. Although form $D$ fair values and net settlements may be related to the magnitude of market exposure, the information needed to accurately gauge that exposure is not collected. Fair values are a weak proxy for market exposure for several reasons. One reason is that a positive fair value does not indicate the direction of exposure; depending on the nature of the contract, the value of the derivative may either increase or decrease when the value of the underlying increases.

Another source of difficulty in gauging market exposure is that derivatives can be highly leveraged. Accordingly, small movements in the value of the underlying can cause very large changes in the fair value. The net aggregate fair value may include both the fair values of contracts with high leverage and those of contracts with little or no leverage. Finally, the $\mathrm{D}$ data provide at most a partial picture of reporters' market exposure because they include no information about positions with offsetting risks.

Nevertheless, a rough estimate of the exposure to the underlyings may be constructed by examining the changes in quarter-end fair values and net settlements. For example, a comparison of the valuation changes implied by the reported quarter-end net fair values and net settlements of single-currency interest rate contracts with the quarter-end moves in interest rates can be used to construct a rough estimate of the aggregate exposure to underlying interest rates (refer to box "Implied Valuation Change"). However, this analysis may be misleading because of changes in the number of derivatives contracts within the quarter.

\section{SUMMARY}

This article introduced the new data on transactions in, and holdings of, U.S. cross-border derivatives and discussed the new form that will collect the dataTIC form D. To date, the United States has published very little information on cross-border derivatives because of the limited availability of data. The article showed how the omission of derivatives from reports on cross-border flows and positions gives rise to a statistical discrepancy in the BOP accounts and can also lead to mistaken inferences about what is driving changes in the international investment position of the United States.

The article demonstrated how the information collected on form D substantially improves the reporting of both the BOP and the IIP. Because the compilers of the financial account will have the information needed to include derivatives transactions in that account, the contribution of derivatives to the statistical discrepancy will be reduced. Similarly, the fair values and transaction information collected on form D will enable the compilers of the IIP to include derivatives contracts, thereby improving the IIP's accuracy.

The article also presented the results from the 2006 form $\mathrm{D}$ data and showed that they are consistent with expectations. For example, although including the 2006 data on total form D net settlements in the BOP would not erase the statistical discrepancy, it would reduce it in that year. Moreover, when U.S. transactions are included, net world transactions in derivatives in 2006 are closer to zero. Finally, including the U.S. position moves the net world position closer to zero. Although the data collected thus far are consistent with expectations, the Treasury Department, the Federal Reserve Bank of New York, and the Federal Reserve Board continue to seek ways to improve data quality and reduce the burden on reporters. 